\title{
Análise da dinâmica espacial e temporal do uso e ocupação do solo no município de Condado-PB (1989- 2018)
}

Analysis of the spatial and temporal dynamics of land use and occupancy in the municipality of Condado-PB (1989-2018)

Análisis de la dinámica espacial y temporal del uso y ocupación del suelo en el municipio de Condado-PB (1989-2018)

\author{
Renato de Bozzano Rodrigues \\ ORCID: https://orcid.org/0000-0003-1913-5143 \\ Universidade Federal de Pernambuco, Brasil \\ E-mail: renato_fip@hotmail.com \\ Sérgio Murilo Santos de Araújo \\ ORCID: https://orcid.org/0000-0001-9599-4383 \\ Universidade Federal de Campina Grande, Brasil \\ E-mail: sergiomurilosa.ufcg@gmail.com \\ Magdiel Ferreira Bezerra \\ ORCID: https://orcid.org/0000-0002-2373-8118 \\ Universidade Federal de Campina Grande, Brasil \\ E-mail: magdielferreirapicui@ hotmail.com \\ Lázaro Avelino de Sousa \\ ORCID: https://orcid.org/0000-0001-6505-1288 \\ Universidade Federal de Campina Grande, Brasil \\ E-mail: lazaroavelino@hotmail.com
}

\begin{abstract}
Resumo
A adaptação do meio ambiente às necessidades humanas altera a configuração natural das paisagens ao longo dos anos, refletindo as formas de uso e ocupação do solo. Os processos de uso e ocupação inerentes a configuração das paisagens são concomitantes, uma vez que a deflagração do primeiro processo (uso) altera o panorama do segundo (ocupação). Nesse sentido, as ações antrópicas sobre o meio ambiente estão no centro dessa problemática. No Semiárido Brasileiro o processo de uso e ocupação do solo sofre influência de práticas tradicionais peculiares àquela região, a exemplo da agricultura de sequeiro e da pecuária tradicional. Com o intuito de avaliar a influência destas práticas na configuração espaço-temporal das paisagens, este trabalho teve como objetivo analisar a dinâmica espaçotemporal do uso e ocupação do solo no município de Condado-PB, no período de 1989 a 2018, através do Índice de Vegetação Ajustado ao Solo (IVAS). Esta técnca de Sensoriamento remoto permitiu a elaboração e análise de mapas de uso e ocupação do solo através do processamento digital de imagens dos satélites Landsat 5 - TM e Landsat 8 OLI. Foram identificadas 5 classes de uso e ocupação, sendo a vegetação classificada em arbórea, arbustiva e gramínea (ou herbácea), além das classes solo exposto e corpos d'água. Os resultados mostraram aumento nas classes de vegetação arbórea $(105,44 \%)$, gramínea/herbácea $(386,96 \%)$ e nos corpos d'água $(179,33 \%)$. A vegetação arbustiva e o solo exposto diminuíram $2,92 \%$ e $62,6 \%$ respectivamente. No geral, a vegetação cresceu em área ocupada de 44,9\% em 1989, para 70,9\% em 2018.
\end{abstract}

Palavras-chave: Degradação das terras; Geoprocessamento; Caatinga; Semiárido brasileiro.

\begin{abstract}
The adaptation of the environment to human needs alters the natural configuration of landscapes over the years, reflecting the forms of land use and occupation. The processes of use and occupation inherent to the configuration of landscapes are concomitant, since the outbreak of the first process (use) alters the panorama of the second (occupation). In this sense, human actions on the environment are at the center of this problem. In the Brazilian semiarid region, the process of land use and occupation is influenced by traditional practices peculiar to that region, such as rainfed agriculture and traditional livestock farming. In order to evaluate the influence of these practices on the space-time configuration of landscapes, this work aimed to analyze the space-time dynamics of land use and occupation in the municipality of Condado-PB, from 1989 to 2018, through the Soil Adjusted Vegetation Index (IVAS). This remote sensing technique allowed the elaboration and analysis of maps of land use and occupation through the digital processing of images from the Landsat 5 - TM and Landsat 8 - OLI satellites. Five classes of use
\end{abstract}


and occupation were identified, with the vegetation classified as arboreal, shrubby and grassy (or herbaceous), in addition to exposed soil and water bodies. The results showed an increase in the classes of arboreal vegetation $(105.44 \%)$, grass/herbaceous $(386.96 \%)$ and water bodies $(179.33 \%)$. Shrub vegetation and exposed soil decreased by $2.92 \%$ and $62.6 \%$ respectively. Overall, vegetation grew in occupied area from $44.9 \%$ in 1989 to $70.9 \%$ in 2018 .

Keywords: Land degradation; Geoprocessing; Caatinga; Brazilian semi-arid.

\section{Resumen}

La adaptación del medio ambiente a las necesidades humanas cambia la configuración natural de los paisajes a lo largo de los años, reflejando las formas de uso y ocupación del suelo. Los procesos de uso y ocupación inherentes a la configuración de los paisajes son concomitantes, ya que el estallido del primer proceso (uso) altera el panorama del segundo (ocupación). En este sentido, las acciones humanas sobre el medio ambiente están en el centro de este problema. En la región semiárida brasileña, el proceso de uso y ocupación de la tierra está influenciado por prácticas tradicionales propias de esa región, como la agricultura de secano y la ganadería tradicional. Con el fin de evaluar la influencia de estas prácticas en la configuración espacio-temporal de los paisajes, este trabajo tuvo como objetivo analizar la dinámica espacio-temporal del uso y ocupación del suelo en el municipio de Condado-PB, desde 1989 hasta 2018, a través del Suelo Ajustado. Índice de Vegetación (IVAS). Esta técnica de teledetección permitió la elaboración y análisis de mapas de uso y ocupación del suelo a través del procesamiento digital de imágenes de los satélites Landsat 5 - TM y Landsat 8 - OLI. Se identificaron cinco clases de uso y ocupación, clasificando la vegetación en arbórea, arbustiva y herbácea (o herbácea), además de suelos expuestos y cuerpos de agua. Los resultados mostraron un aumento en las clases de vegetación arbórea (105,44\%), gramíneas/herbáceas (386,96\%) y cuerpos de agua (179,33\%). La vegetación arbustiva y el suelo expuesto disminuyeron un 2,92\% y un $62,6 \%$ respectivamente. En general, la vegetación creció en el área ocupada del 44,9 \% en 1989 al 70,9 \% en 2018.

Palabras clave: Degradación de la tierra; Geoprocesamiento; Caatinga; Región semiárida brasileña.

\section{Introdução}

Esta pesquisa concebe como dinâmica de uso e ocupação do solo o processo físico-biológico, de dimensão espaçotemporal, que envolve fatores naturais e antrópicos, atuante sobre a configuração paisagística da parte superior da crosta terrestre, denominada solo. O uso do solo está relacionado aos processos antrópicos, enquanto a ocupação considera o aspecto físico natural do meio ambiente.

A concepção paisagística referida nesta abordagem se apoia no conceito de paisagem adotado na Geografia, segundo o qual "a paisagem é - em uma determinada porção do espaço - o resultado da combinação dinâmica, portanto instável, de elementos físicos, biológicos e antrópicos que, reagindo dialeticamente uns sobre os outros, fazem da paisagem um conjunto único e indissociável, em perpétua evolução" (Bertrand, 2014).

Os processos de uso e ocupação do solo inerentes a configuração das paisagens são concomitantes, uma vez que a deflagração do primeiro processo (uso) altera o panorama do segundo (ocupação). Nesse sentido, as ações antrópicas sobre o meio ambiente estão no centro das discussões sobre a problemática de uso e ocupação aqui referidas. A relação do homem com a natureza tem sido o enfoque de diversos estudos da atualidade, sendo a análise da dinâmica da paisagem uma forma de demonstrar como ocorre as mudanças de diversos componentes do meio ao longo dos anos (Dutra et al., 2020).

A exploração dos recursos ambientais pelos seres humanos é o principal fator deflagrador das alterações verificadas no panorama paisagístico do uso e ocupação do solo ao longo dos anos. A dinâmica dessas alterações é passível de ser analisada cronologicamente através de técnicas de Sensoriamento Remoto e Geoprocessamento que, através de Sistemas de Informação Geográfica (SIGs) e softwares especializados em processamento digital de imagens de satélite, fornecem mapas analíticos da situação do uso e ocupação do solo em diferentes períodos de tempo. Por meio desses mapeamentos é possível gerar modelos de quantificação de biomassa ou detectar anomalias fenológicas presentes na vegetação nativa, permitindo a análise da degradação da vegetação e dos impactos ambientais (Lima Júnior, et al 2014 \& Liu et al, 2019).

Uma das aplicações do Sensoriamento Remoto para o mapeamento dos tipos de uso e ocupação do solo considera a estimativa de índices de vegetação calculados através de softwares especializados em Geoprocessamento de imagens de satélite. De acordo com Ribeiro, Silva e Silva (2016), tais índices de vegetação são adquiridos por combinações matemáticas 
das reflectâncias de duas ou mais bandas ou faixas do espectro eletromagnético da Terra, e têm como objetivo, em princípio, extrair informações espectrais da cobertura da superfície da terra, discriminando a vegetação da superfície não vegetada.

Os principais índices de vegetação utilizados em estudos de uso e ocupação do solo são o Índice de Vegetação por Diferença Normalizada (IVDN) e o Índice de Vegetação Ajustado ao Solo (IVAS). Este último é indicado para áreas de estudo em que haja muita relevância da resposta espectral do solo em detrimento dos demais elementos contidos na imagem, como é o caso de áreas de Caatinga, onde a maioria das espécies vegetais perde as folhas no período seco, gerando confusão sobre o que seria solo exposto ou superfície vegetada nas imagens analisadas. De acordo com Machado, Galvíncio e Oliveira (2011), a utilização do IVAS é preferível em áreas com estas características, pois este índice utiliza um fator de correção (denominado de constante "L") que minimiza as variações de brilho do solo na resposta espectral da área analisada.

Empiricamente, sabe-se que na Região Semiárida brasileira, práticas tradicionais como agricultura de sequeiro, extração de lenha para cocção de alimentos, plantio de culturas irrigadas e pastoreio de rebanhos bovinos estão entre as principais atividades rurais que influenciam a configuração das paisagens, interferindo no panorama do uso e ocupação do solo ao longo dos anos. Figueiredo et al (2017) afirmam que as principais causas da degradação da Caatinga ocorrem por conta da pecuária tradicional em prol do abastecimento das comunidades humanas. Souza et al (2019) ressalta que apesar de todas essas interferências antrópicas, o bioma a Caatinga faz parte do grupo dos biomas menos protegidos e estudados, apresentando uma grande variedade fisionômica, que resulta da elevada variação das condições ambientais, destacando-se o clima e a pedogênese.

No município de Condado, no Sertão Paraibano, estas práticas tradicionais supracitadas estão presentes na formação paisagística do lugar, representando os principais tipos de ação antrópica atreladas ao uso e ocupação do solo. O perímetro irrigado do açude Engenheiro Arcoverde é um exemplo de uso do solo que representa uma peculiaridade deste município, com destaque para a produção de frutas como Banana, Goiaba, Manga, Coco, entre outras.

Com o intuito de conhecer a evolução paisagística do lugar ao longo do tempo, bem como os principais fatores atrelados a esta evolução, este trabalho teve como objetivo analisar a dinâmica espaço-temporal do uso e ocupação do solo no município de Condado-PB, no período de 1989 a 2018, através do Índice de Vegetação Ajustado ao Solo (IVAS).

\section{Metodologia}

\section{Localização e caracterização da área de estudo}

O Estudo foi conduzido no município de Condado, no Estado da Paraíba, localizado na mesorregião do Sertão Paraibano e microrregião de Sousa, sob as coordenadas 6 $54^{\prime} 30^{\prime \prime}$ S e $37^{\circ} 35^{\prime} 50^{\prime}$ ' O. Com aproximadamente 250 metros de altitude, Condado limita-se com os municípios de Paulista e Vista Serrana ao norte; Vista Serrana e Malta a leste; Catingueira ao sul; Pombal, São Bentinho e Cajazeirinhas a oeste. A sede municipal situa-se a uma altitude de 241 metros, com coordenadas de 9.235.970 NS e 854.565 EW e está a uma distância de 362 km da capital paraibana João Pessoa (Instituto Brasileiro de Geografia e Estatística [IBGE], 2018a). O município possui área territorial de $280 \mathrm{~km}^{2}$, conforme Shapefile do IBGE (2018b) (Figura 1). 
Figura 1 - Localização do município de Condado-PB.

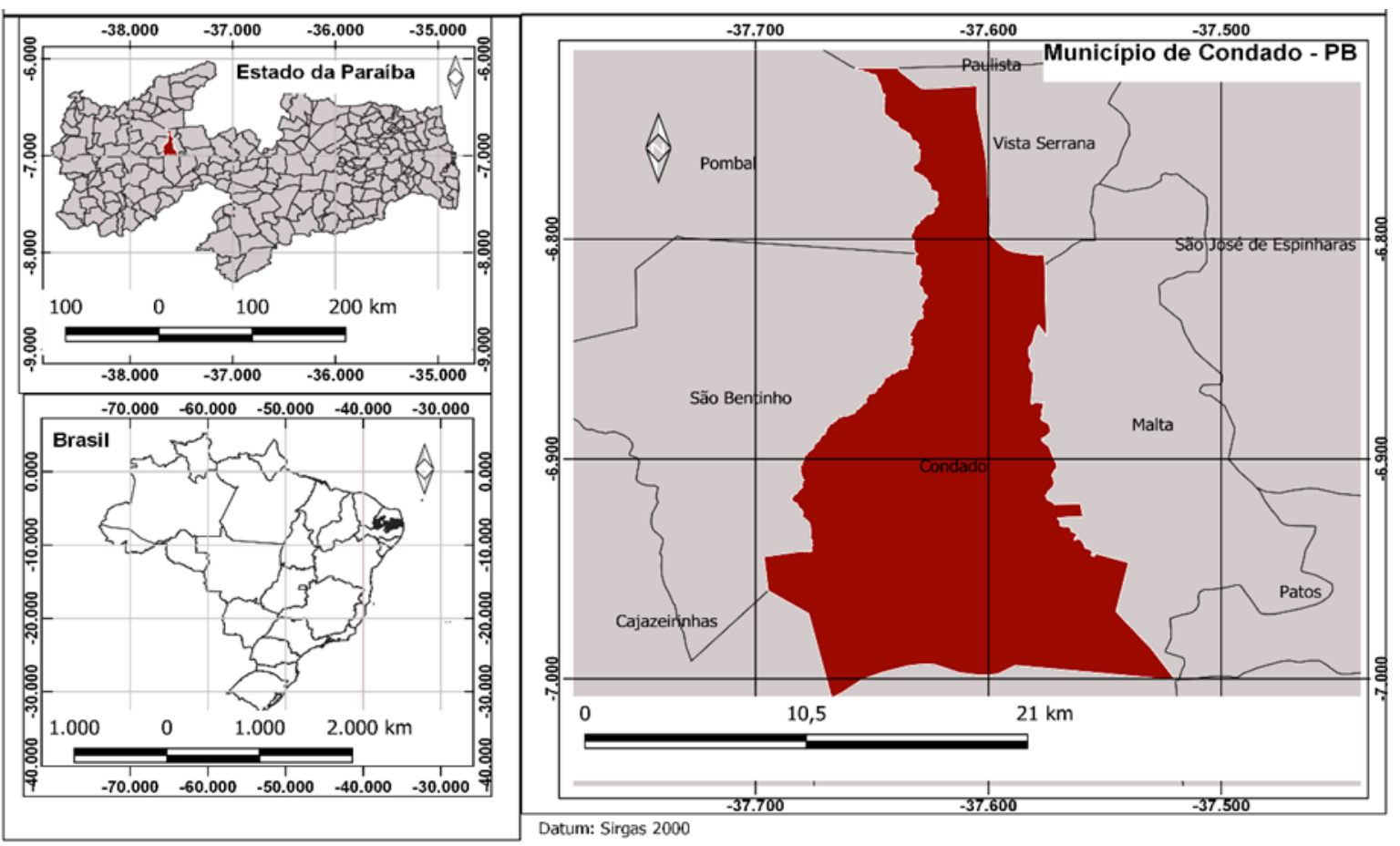

Fonte: Autores (2020) com dados do IBGE (2018).

O município de Condado encontra-se inserido nos domínios da bacia hidrográfica do Rio Piranhas, região do médio Piranhas. Os principais cursos d'água são os riachos da Caiçara, Pau Branco, Morcego, da Furna, São Francisco, São Vicente, dos Borges, do Cipó, Pedra d' Água, Manuela, Macapá, do Juá, das Assentadas e os córregos Covão e Catolé. Todos os cursos d'água da bacia têm regime de escoamento intermitente e o padrão de drenagem é o dendrítico. O principal corpo de acumulação hídrica é o Açude Engenheiro Arcoverde (36.834.375 m³), cuja bacia hidrográfica apresenta uma área de 124 km².

O clima no município, segundo a classificação de Köppen, é do tipo Aw' (quente e úmido com chuvas de verão e outono). Em escala estadual, considerando as regiões bioclimáticas, o município de Condado possui clima 4a Th (tropical quente com seca acentuada, com sete a oito meses secos). A pluviometria média anual é de $781 \mathrm{~mm}$ e a distribuição das chuvas durante o ano é irregular com 78\% de seu total concentrando-se em cinco meses, entre janeiro e maio (Rodrigues, 2019).

A vegetação de Condado é do tipo Caatinga, predominando as espécies de porte arbustiva e herbácea, com poucas arbóreas de pequeno porte. A temperatura média anual situa-se entre 26 e $27{ }^{\circ} \mathrm{C}$. A topografia dos terrenos apresenta-se predominantemente com relevo variando de ondulado a suavemente ondulado com declividade média baixa, com exceção de áreas localizadas na porção sul, de relevo ondulado a fortemente ondulado, com declividade média elevada, como ocorre no Serrote Comprido, Serras da Esperança, Rio de Janeiro e José Pereira; a leste, no serrote do Poldrinho; e ao norte, nas Serras Vermelha, dos Miguéis e dos Pilões (Serviço Geológico do Brasil [CPRM], 2005).

\section{Aquisição e utilização das imagens de satélite}

As imagens orbitais utilizadas neste estudo foram produzidas pelos satélites Landsat-5, sensor TM (Thematic Mapper) e Landsat-8, sensor OLI (Operational Land Imager), e foram adquiridas no site oficial do Instituto Nacional de Pesquisas Espaciais (INPE) (https://www.gov.br/inpe/pt-br). As imagens correspondem aos anos de 1989, 1999, 2009 e 2018, e possuem resolução espacial de 30m de pixel ao solo, com períodos de coleta das imagens correspondendo ao período seco. Na escolha das imagens levou-se em consideração, além da resolução das mesmas, a disponibilidade de imagens com baixa ou nenhuma incidência de nuvens. O recorte das imagens foi feito segundo os contornos do município de Condado obtidos em arquivo 
Shapefile disponibilizado pelo IBGE.

Para a identificação do período de coleta das imagens (período seco) elaborou-se um climograma da região envolvida no estudo a partir do Banco de Dados Climáticos do Brasil (Empresa Brasileira de Pesquisa Agropecuária [EMBRAPA] 2018). As configurações hipsométricas da área de estudo foram obtidas através do Modelo Digital de Elevação (MDE) elaborado a partir de imagens SRTM (Shuttle Radar Topography Mission) com resolução de 90m e sistema de coordenadas WGS84. Como ferramenta de geoprocessamento e georreferenciamento das imagens obtidas foi utilizado o software livre QGis 2.18 Las Palmas.

Com o intuito de complementar as informações foram realizadas visitas a campo com a finalidade de coletar dados e informações acerca das principais atividades desenvolvidas na área. Como ferramenta na captação de imagens das paisagens locais foi utilizada Câmera fotográfica digital com resolução de 16 MP, integrada ao smartphone Samsung Galaxy A6 plus.

\section{Índice de Vegetação Ajustado ao Solo}

O Índice de Vegetação Ajustado ao Solo (IVAS), ou, em inglês, Soil Adjusted Vegetation Index (SAVI) é um índice derivado de adequações feitas por Huete (1988) ao constatar que o Índice de Vegetação por Diferença Normalizada (IVDN) ou, em inglês, Nomalized Diference Vegetation Index (NDVI) apresentava algumas variações em regiões onde a vegetação é de baixa densidade. Isso levou Huete à criação de um novo índice, denominado de SAVI, o qual tem melhor desempenho em áreas de baixa cobertura vegetal, sendo este uma melhoria do NDVI a partir da aplicação da constante "L", minimizando os efeitos do brilho do solo nos seus resultados.

O SAVI ou IVAS pode ser obtido a partir da aplicação da seguinte equação (Equação 1).

$$
\mathrm{SAVI}=(\mathrm{IVP}-\mathrm{V}) /(\mathrm{IVP}+\mathrm{V}+\mathrm{L}) \cdot(1+\mathrm{L})
$$

Em que: IVP = Banda do Infravermelho Próximo; V = Banda do Vermelho Visível; L = Fator de correção variável.

Para a estimativa do SAVI ou IVAS correspondente aos anos de 1989, 1999 e 2009 foram utilizadas as Bandas 3 e 4 do satélite Landsat-5, sensor TM. A Banda 3 corresponde ao Infravermelho Próximo e a Banda 4 ao Vermelho Visível. Como fator de correção de brilho do solo utilizou-se o valor de 0,5 para a Constante "L" (Equação 2).

$$
\mathrm{SAVI}=(\mathrm{BAND} 3-\mathrm{BAND} 4) /(\mathrm{BAND} 3+\mathrm{BAND} 4+0.5) \cdot(1+0.5)
$$

A Banda 3 do satélite Landsat-5 representa na equação (1) por IVP, caracteriza-se por apresentar um intervalo de comprimento de onda de 0.63 a $0.69 \mu \mathrm{m}$. De acordo com o site do Instituto Nacional de Pesquisas Espaciais (http://www.dgi.inpe.br/), a aplicação dessa Banda permite o bom contraste entre as áreas ocupadas com diferentes tipos de cobertura vegetal; a análise da variação litológica em regiões com pouca cobertura vegetal; o mapeamento da drenagem através da visualização da mata galeria; a definição do entalhe dos cursos dos rios em regiões com pouca cobertura vegetal; e a identificação de áreas agrícolas. Também esta é a banda mais utilizada para delimitar as manchas urbanas, incluindo identificação de novos loteamentos.

Já a Banda 4, caracterizada por representar o intervalo de 0.77 a $0.90 \mu \mathrm{m}$, permite o mapeamento da rede de drenagem e delineamento de corpos de água; a obtenção de informações sobre geomorfologia, solos e geologia; proporciona a análise e o mapeamento de feições geológicas e estruturais; o mapeamento de áreas ocupadas com vegetação que foram queimadas; a visualização de áreas ocupadas com macrófitas aquáticas; e a identificação de áreas agrícolas.

Para o ano de 2018, a estimativa do SAVI para a geração dos mapas de uso e ocupação do solo foi feita a partir das 
Bandas 4 e 5 do satélite Landsat-8, sensor OLI (Equação 3).

$$
\text { SAVI }=(\text { BAND4 }- \text { BAND5) } /(\text { BAND4 +BAND5 + 0.5) } \cdot(1+0.5)
$$

No Landsat-8, a Banda do Vermelho Visível corresponde a Banda 4 e a Banda do Infravermelho Próximo corresponde a Banda 5. A Banda 5 tem um intervalo de 0.85 a $0.88 \mu \mathrm{m}$, apresentando sensibilidade ao teor de umidade das plantas, proporcionando assim a observação do estresse causado na vegetação por desequilíbrio hídrico, tal como perturbações em caso de ocorrer excesso de chuva antes da obtenção da cena pelo satélite.

Todos os cálculos do IVAS ou SAVI foram feitos utilizando-se da Calculadora Raster do Qgis 2.18. Aos resultados obtidos para os índices aplicou-se a paleta de cores Banda Simples Falsa-Cor, esta, variando de azul para elementos negativos, a exemplo dos corpos de água, passando pela tonalidade marrom representando valores intermediários referentes ao solo exposto e, por fim, a tonalidade verde representando a vegetação, dividida em três categorias (arbórea, arbustiva e gramínea ou herbácea).

A geração dos mapas em períodos distintos produziu informações quantitativas sobre os avanços ou reduções da vegetação, dos corpos hídricos e do solo exposto. A partir dessas informações foi possível caracterizar os pontos da área de estudo que sofreram os maiores graus de antropismo decorrentes das práticas agrícolas, da expansão urbana, da agropecuária e outras atividades.

\section{Modelo Digital de Elevação (MDE)}

Os dados para a construção do mapa MDE foram obtidos no site da EMBRAPA-Relevo (https://www.embrapa.br), caracterizados por possuírem resolução espacial de 90 m e configuração de 4.000 pixels por km². As cotas hipsométricas foram representadas através do elemento cor sobre a representação 3D digital. As cores quentes representam as altitudes elevadas e as cores frias as baixas altitudes. Na geração do mapa MDE utilizou-se a paleta de cores Banda Simples Falsa-Cor, variando do marrom ao branco. Para representar o formato 3D foi utilizada a ferramenta 2 threejs do Qgis. O valor de verticalidade aplicado variou de 0.002 a 0.003 . O cálculo de delimitação da bacia, com dados do perímetro e da declividade do terreno, subsidiou a análise dos processos de escoamento superficial recorrentes na área.

\section{Resultados e Discussão}

Para a análise da dinâmica espacial e temporal do uso e ocupação do solo no município de Condado-PB, as imagens de satélite utilizadas na estimativa do SAVI ou IVAS foram captadas levando-se em consideração a estação seca do município (segundo semestre) conforme o climograma representado no Gráfico 1. Esta escolha se deu mediante indicação de Bandeira e Cruz (2021), segundo os quais o índice SAVI enfatiza a influência de solo exposto, especialmente no período seco, quando a vegetação de Caatinga perde suas folhas. 
Gráfico 1: Climograma do município de Condado-PB para o período de 1989 a 2018.

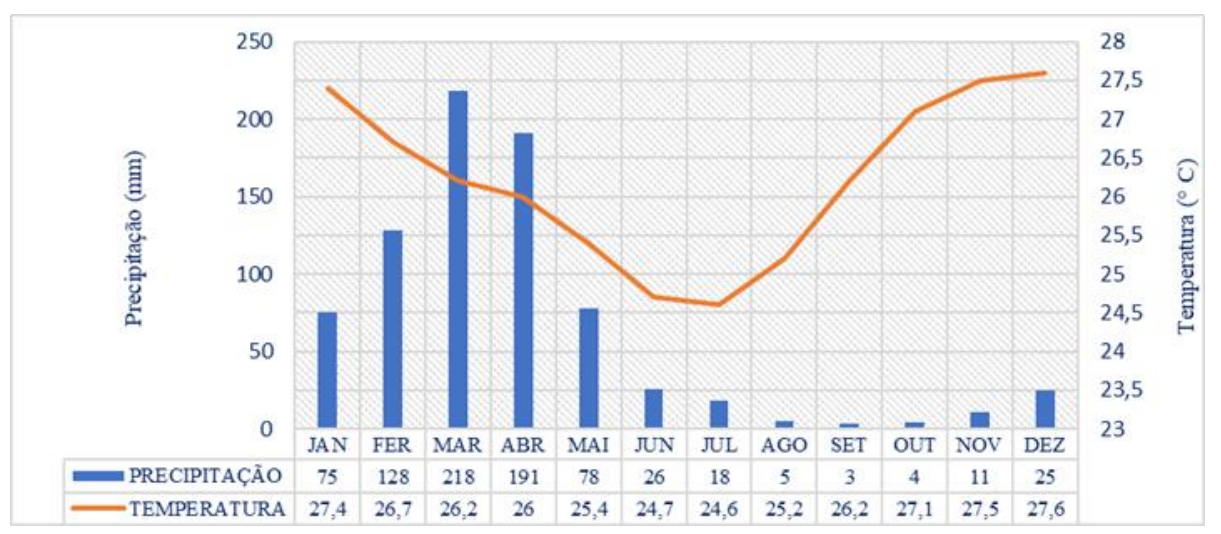

Fonte: Banco de dados climáticos do Brasil (2018) e Autores (2020).

O histórico de médias mensais de temperara e precipitação do município de Condado-PB, representado no Gráfico 1, corresponde a um período observado de 29 anos. Pelas médias registradas tem-se que o período seco no município compreende o segundo semestre do ano, em que as temperaturas aumentam a partir do mês de julho, com variação positiva de aproximadamente $3^{\circ} \mathrm{C}$ até o mês de dezembro. As médias mensais pluviométricas de junho (26 mm) a dezembro (25 mm) são baixas e sofrem redução significativa nos meses de julho a novembro.

Para evidenciar a influência que o escoamento superficial exerce na dinâmica hídrica e vegetal da área de estudo, elaborou-se um Modelo Digital de Elevação (MDE) que delimita a bacia de drenagem do município de Condado (Figura 2). Sabe-se que as variáveis geomorfométricas do terreno - para além do escoamento superficial das águas - exercem influência também sobre o tipo de vegetação que ocupa determinada porção do território. Bispo, Valeriano e Kuplich (2010) confrontaram variáveis geomorfométricas com mapas de vegetação da Reserva Natural de Serra das Almas, entre os Estados do Piauí e Ceará, e verificaram que as variáveis mais importantes na distinção entre os tipos vegetacionais foram a elevação, a declividade e a curvatura vertical do terreno. Os referidos autores asseguram que os dados geomorfométricos do terreno representaram significativos insumos para o mapeamento fitogeográfico, devendo ser explorados de forma integrada, em complementaridade à outras variáveis.

Figura 2 - Modelo de Elevação Digital (MDE) do município de Condado-PB e do entorno.

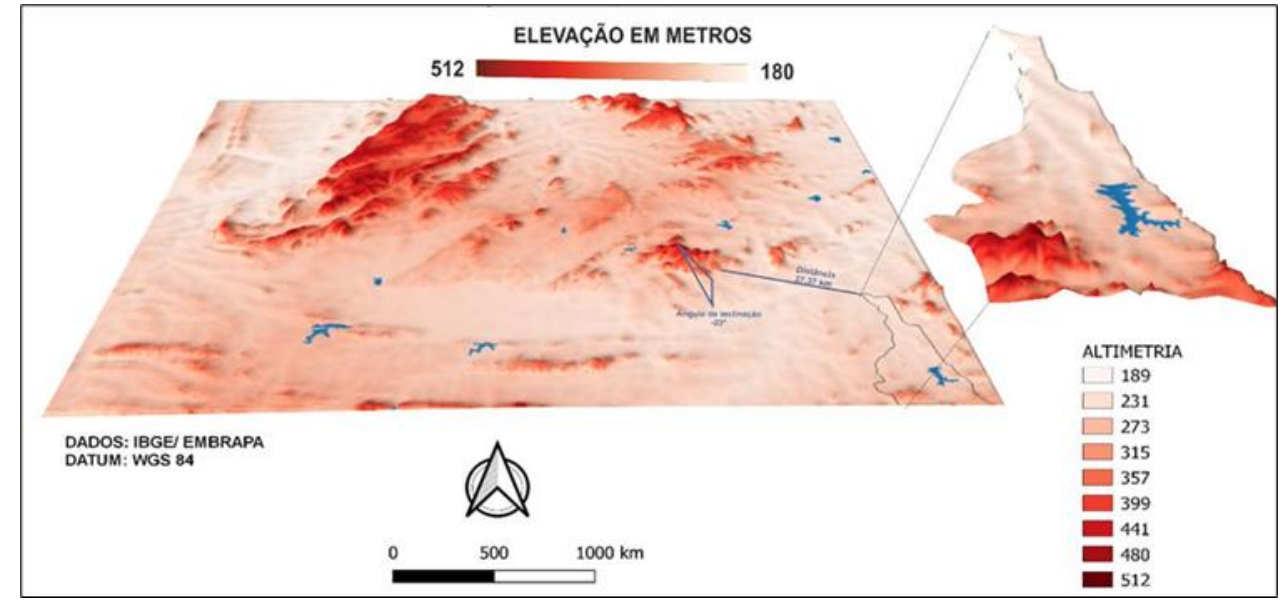

Fonte: Renato Rodrigues e Magdiel Bezerra (2019).

No Modelo Digital de Elevação do terreno elaborado para o município de Condado observou-se que a bacia de 
drenagem do município apresenta a predominância de altitudes abaixo de $357 \mathrm{~m}$, sendo exceção as áreas limítrofes com o município de Catingueira-PB, ao sul, que apresentam relevo fortemente ondulado próximo dos $400 \mathrm{~m}$ de altitude.

Sobrepondo-se a resposta espectral do SAVI ao MDE gerado, nota-se que nas maiores altitudes predomina a ocorrência de solo exposto, enquanto as demais classes de vegetação estão distribuídas nas porções menos elevadas e mais planas do município. Pondere-se que, apesar das maiores altitudes representarem as regiões serranas - de vegetação tipicamente mais conservada - as espécies da Caatinga são caducifólias e perdem suas folhas no período seco, dando maior visibilidade ao solo. Ademais, no período seco a vegetação serrana é cortada e utilizada como lenha para a cocção de alimentos, fator este que também contribui para uma maior visibilidade do solo exposto nessas áreas.

\section{Análise do uso e ocupação do solo no ano de 1989}

A análise do uso e ocupação do solo em 26/09/1989 compreendeu toda a extensão do município. A princípio, a observação visual do produto SAVI coloca em evidência uma grande área verde situada a jusante do açude Engenheiro Arcoverde. Esta área compreende o perímetro irrigado com mesmo nome do açude, no qual mesmo tratando-se de um período seco ainda era mantida a irrigação dos cultivos por meio de poços artesianos, canais de irrigação superficial e irrigação por gravidade, garantindo a reflectância espectral referente à vegetação arbórea e arbustiva, conforme também foi observado em campo.

A Figura 3 representa uma área de $280 \mathrm{~km}^{2}$, correspondendo a 100\% do território do município de Condado- PB, distribuída em cinco classes, com valores negativos relacionados aos corpos d'água e progressivamente relacionados à densidade da vegetação. A tonalidade de cores varia do azul, para os corpos d'água, a verde escuro, para a vegetação arbórea.

Figura 3 - Mapa das classes do SAVI do município de Condado/PB - 1989.

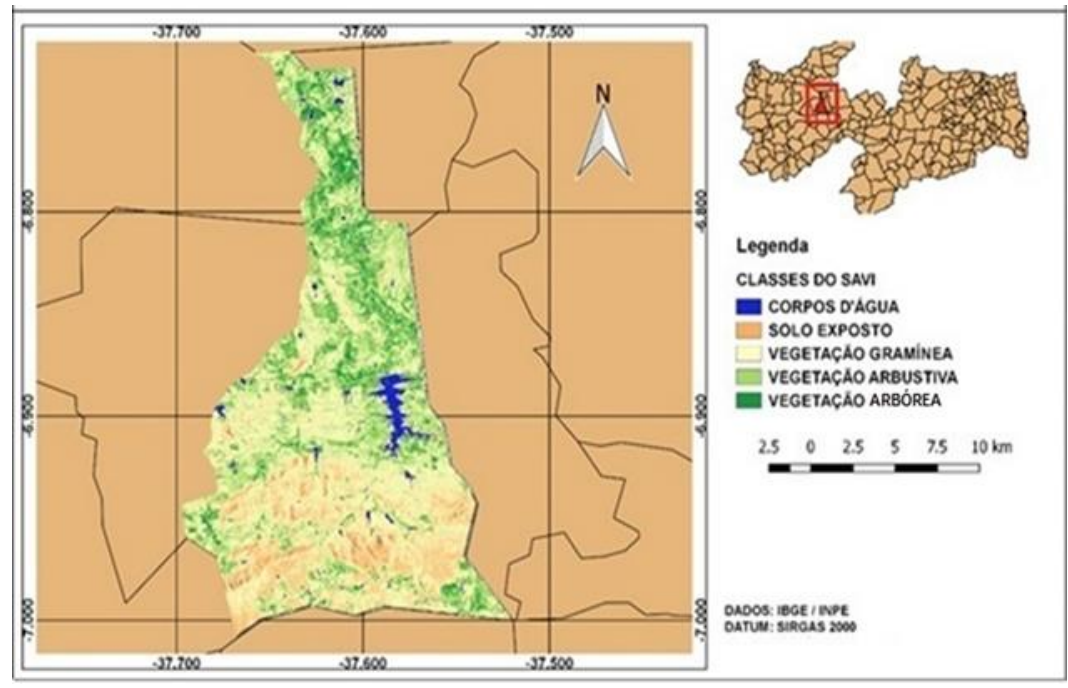

Fonte Fonte: Renato Rodrigues e Magdiel Bezerra (2018).

A análise da ocupação do solo mostra que a maior parte do município corresponde a classe de solo exposto, localizados principalmente ao sul, com extensão de $149,72 \mathrm{~km}^{2}$, que representam 53,6\% da área total do município. Essa região ocupa porções de áreas não irrigadas onde se desenvolve, como base da economia municipal, a criação de gado e a agricultura de sequeiro. A extração de madeira como combustível era prática comum na época representada na imagem. Grande parte da população, principalmente na zona rural, não dispunha de outra fonte energética e utilizava a madeira para a produção de carvão.

Com bastante similaridade, Aragão et al (2021) analisaram a degradação ambiental no município de Gado Bravo-PB 
utilizando imagens Landsat-5 do ano de 1989 e Landsat-8 de 2014. Estes autores identificaram vários níveis de degradação do solo que variaram de baixo a muito grave, de acordo com os índices de cobertura vegetal apresentados. Apesar de não utilizar o SAVI como parâmetro, o estudo analisou a ocupação do solo por vegetação Caatinga no mesmo período considerado em Condado, com diferença de apenas 4 anos, e utilizou imagens dos mesmos satélites. As imagens de 1989 revelaram uma extensa área de degradação na parte central do município que os autores atribuíram às atividades agrícola e pecuária, bem como à retirada da vegetação de maior porte para dar espaço a produção de ração bovina, palma forrageira, milho e sorgo.

Em Condado, a baixa reflectância da vegetação gramínea (ou herbácea) não a distingue com exatidão do solo exposto; no entanto, esta classe representava $4,1 \%$ da área ou $11,51 \mathrm{~km}^{2}$ (Tabela 1). A vegetação arbustiva representou $26 \%$, o equivalente a 73,03 km², estando espaçada por toda a região norte e oeste e uma pequena fração a sudeste, na região limítrofe com os municípios de Malta e Catingueira. A maior presença desse tipo de cobertura vegetal na área de jusante do reservatório se dá em virtude das áreas de culturas temporárias e permanentes do perímetro irrigado.

Tabela 1 - Classes de cobertura SAVI do município de Condado-PB - 1989.

\begin{tabular}{lcc}
\hline \multicolumn{1}{c}{ Classes } & Área $\left.\mathbf{( k m}^{2}\right)$ & Percentual (\%) \\
\hline Vegetação arbórea & 41,57 & 14,8 \\
Vegetação arbustiva & 73,03 & 26 \\
Vegetação gramínea (ou herbácea) & 11,51 & 4,1 \\
Solo exposto & 149,72 & 53,6 \\
Corpos d'água & 4,21 & 1,5 \\
\hline \multicolumn{1}{c}{ Total } & $\mathbf{2 8 0}$ & $\mathbf{1 0 0}$ \\
\hline
\end{tabular}

Fonte: Elaborado por Renato Rodrigues (2018)

Outro fator que apresentou relevância na região do perímetro irrigado foi a vegetação arbórea, evidenciada na área de mata ciliar do açude e de outros corpos d'água, com uma representação de 14,8\%, em extensão territorial, que correspondia a uma área de $41,57 \mathrm{~km}^{2}$.

No ano analisado a maior parte da população residia em áreas rurais ao sul do território, em propriedades do governo federal, distribuídas em lotes na forma de arrendamento a pequenos produtores, esse fator demográfico pode ter sido determinante na distribuição da cobertura vegetal apresentada.

Outro fator relevante para a presença de mata ciliar, se deu em virtude da constante atuação de fiscalização do DNOCS (Departamento Nacional de Obras Contra a Seca) no açude Engenheiro Arcoverde contra a expansão das atividades agropecuárias na região circundante ao reservatório.

\section{Análise do uso e ocupação do solo no ano de 1999}

De acordo com as análises do SAVI, a classe com maior representatividade no ano de 1999 corresponde à vegetação arbórea, que cobria 35,5\% do território, com extensão de $99,4 \mathrm{~km}^{2}$. A vegetação arbustiva, com $28,3 \%$, era o equivalente a $79,24 \mathrm{~km}^{2}$, representando a segunda maior expressão no território. O solo exposto se apresenta com 13,2\%, equivalendo a $36,96 \mathrm{~km}^{2}$; enquanto os corpos d'água apareceram com apenas 3\% de toda a área, com extensão de apenas 8,4 km² (Tabela 2).

O mapa da Figura 4 representa a classificação no terreno. 
Tabela 2 - Classes de cobertura SAVI de Condado-PB - 1999.

\begin{tabular}{lcc}
\hline \multicolumn{1}{c}{ Classes } & Área $\left(\mathbf{k m}^{\mathbf{2}}\right)$ & Percentual (\%) \\
\hline Vegetação arbórea & 99,4 & 35,5 \\
Vegetação arbustiva & 79,24 & 28,3 \\
Vegetação gramínea (ou herbácea) & 56 & 20 \\
Solo exposto & 36,96 & 13,2 \\
Corpos d'água & 8,4 & 3 \\
\hline \multicolumn{1}{c}{ Total } & $\mathbf{2 8 0}$ & $\mathbf{1 0 0}$ \\
\hline
\end{tabular}

Fonte: Elaborado por Renato Rodrigues (2018).

Figura 4 - Mapa do índice SAVI no município de Condado - PB - 1999.

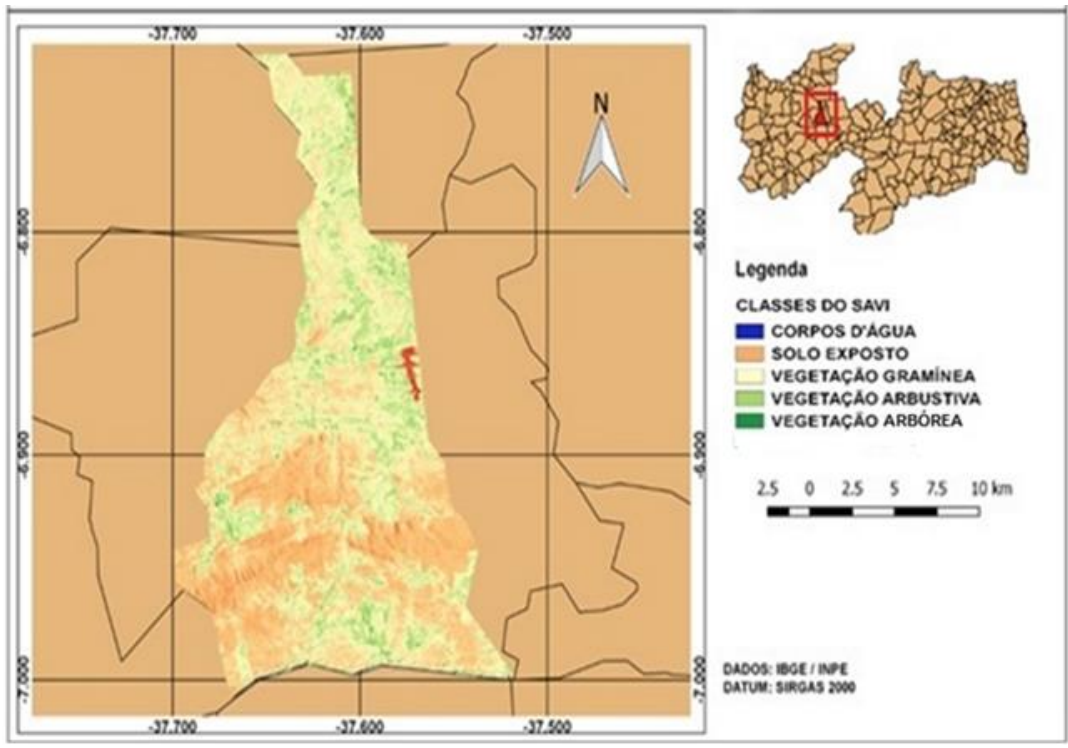

Fonte: Elaborado por Renato Rodrigues (2018).

Os valores do SAVI apresentaram uma redução significativa do solo exposto, se comparados aos valores do ano de 1989. Em contrapartida, as classes de vegetação e corpos d'água representaram um percentual maior da área. Quando se compara a distribuição das coberturas com as obtidas há dez anos, a classe de vegetação arbórea, considerada de grande porte, apresentou crescimento significativo de 20,7\%. Outra classe de vegetação que apresentou progressão no território foi a vegetação gramínea (ou herbácea), registrando um crescimento de $15,9 \%$.

A vegetação arbustiva, embora tenha apresentado registro de menor expressão, aumentou em 2,3\% sua cobertura no mesmo período. Em síntese, a soma da progressão apresentada pelas classes de cobertura vegetal totalizou a importância de 38,9\%. Os corpos hídricos também apresentaram crescimento de 1,5\%. Contrariamente ao expressivo crescimento da vegetação, os solos expostos apresentaram um decréscimo de 40,1\%.

O crescimento das classes vegetais no recorte temporal analisado se dá em virtude do baixo antropismo e das condições de precipitação apresentadas. De acordo com os dados meteorológicos fornecidos no site da Agência Executiva de Gestão das Águas do Estado da Paraíba - AESA-PB (www.aesa.pb.gov.br/), as precipitações ao longo do ano de 1999 estiveram dentro dos padrões esperados para região $(781 \mathrm{~mm})$, sendo este o possível fator responsável pelas vegetações arbustiva e gramínea, consideradas de pequeno porte, apresentarem maior cobertura de refletância na área. Outro fator que pode explicar o significativo crescimento destas classes de vegetação está relacionado aos processos demográficos, conforme se explica a seguir. 
Com base nas análises dos censos demográficos do IBGE dos anos de 1991 e 2010, observa-se a redução da população absoluta do município de Condado, onde em 1991 contava com a população residente de 7.399 habitantes, diminuindo para 6.495 habitantes no ano 2000. Gobbi (2019) explica que é comum da dinâmica demográfica da região Nordeste o fluxo migratório em relação à outras regiões do país. Este autor afirma que o Nordeste foi uma das regiões que mais migraram pessoas para outras regiões, em decorrência da baixa capacidade da economia das cidades em atrair a população do campo para os centros urbanos, como acontece nas regiões Sudeste e Centro-Oeste. Contudo, o que foi observado no município de Condado no período analisado foi que o êxodo rural elevou a população urbana ao percentual de 63,53\%, enquanto a população rural se restringiu a 36,47\%. Batista, Moura, Silva e Andrade (2018), analisando o êxodo rural no Nordeste Brasileiro, afirma que nos Estados do Ceará, Rio Grande do Norte, Paraíba e Pernambuco os municípios que recebem baixo crédito rural em custeio estão cercados por municípios que possuem, em média, baixa população rural. A partir desta constatação os autores explicam que a baixa produtividade do setor rural no sertão desses Estados é um fator de alto risco que incide em uma baixa concessão de crédito, gerando assim uma baixa atratividade do pequeno produtor em permanecer na área rural.

A redução da densidade populacional absoluta, juntamente com a densidade populacional rural no município de Condado, pode ter levado à diminuição das ações antrópicas, possibilitando a resiliência da vegetação em diferentes extratos. Já o aumento da relevância dos corpos hídricos nos dados analisados deveu-se a condição hídrica do açude Engenheiro Arcoverde, que de acordo com o monitoramento dos corpos hídricos da AESA-PB, apresentava em 1999 volume de $9.164 .850 \mathrm{~m}^{3}, 30 \%$ da sua capacidade total.

\section{Análise do uso e ocupação do solo no ano de 2009}

Na avaliação do índice SAVI relativo a 19/09/2009 o cálculo da área espectral apresenta-se com a classe vegetal preponderando sobre o solo exposto, e os valores referentes a vegetação arbórea atingem o percentual de $28 \%$. Transformando esse número em dimensão de área obtém-se a cobertura de $78,4 \mathrm{~km}^{2}$, representando a maior cobertura dentre as classes selecionadas (Tabela 3).

Tabela 3 - Classes de cobertura, SAVI, para o município de Condado-PB - 2009.

\begin{tabular}{lcc}
\hline \multicolumn{1}{c}{ Classes } & Área $\left(\mathbf{k m}^{\mathbf{2}}\right)$ & Percentual (\%) \\
\hline Vegetação arbórea & 78,4 & 28 \\
Vegetação arbustiva & 72,24 & 25,8 \\
Vegetação gramínea (ou herbácea) & 67,2 & 24 \\
Solo exposto & 45,36 & 16,2 \\
Corpos d'água & 16,8 & 6 \\
\hline \multicolumn{1}{c}{ Total } & $\mathbf{2 8 0}$ & $\mathbf{1 0 0}$ \\
\hline
\end{tabular}

Fonte: Elaborado por Renato Rodrigues (2018).

As coberturas de vegetação arbustiva e gramínea (ou herbácea) são muito próximas, com respostas respectivas de $25,8 \%$ e $24 \%$, representando uma área de 72,24 e 67,2 km², respectivamente. Compilando todos os valores referentes as classes de vegetação, obtém-se o valor percentual de 77,8\% e a cobertura de $217 \mathrm{~km}^{2}$. Mesmo Diante do significativo volume geral, o solo exposto compreendeu $16,2 \%$ ou $45,36 \mathrm{~km}^{2}$. As áreas de corpos d'água somaram 16,8 km², correspondendo ao percentual de $16,8 \%$ dá área.

A observação do mapa SAVI (Figura 5) não permite a definição com clareza das classes dos elementos evidenciados, ocorrendo a sobreposição dos pixels em decorrência da qualidade de resolução da imagem do satélite Landsat-5. A observação 
mais clara foi possível através da aproximação da imagem no software de tratamento. Os pixels não visualizados na imagem foram processados pelo algoritmo de cálculo do software utilizado, gerando assim os números apresentados.

De acordo com Araújo, Souza e Machado (2021), a baixa resolução do pixel dos produtos Landsat (30 m) não permite uma análise mais detalhada quanto a resolução espacial. Porém, imagens de alta resolução possuem um alto custo que inviabiliza, em muitos casos, sua utilização (Fisher et al, 2018, como citado em Neves \& Mucida, 2020, p. 1). Para avaliar a qualidade das respostas espectrais, Neves e Mucida (op. cit.) compararam os índices de vegetação SAVI e NDVI processados a partir de imagens dos satélites CBERS-4 e Landsat-8 (de menor resolução) e Rapideye-3A (de maior resolução) e verificaram que, dependendo do índice, os produtos do CBERS-4 indicaram uma aproximação com os resultados do Rapideye, demonstrando a qualidade do primeiro mesmo diante de sua resolução mais baixa.

Figura 5 - Mapa do SAVI do município de Condado/PB - 2009.

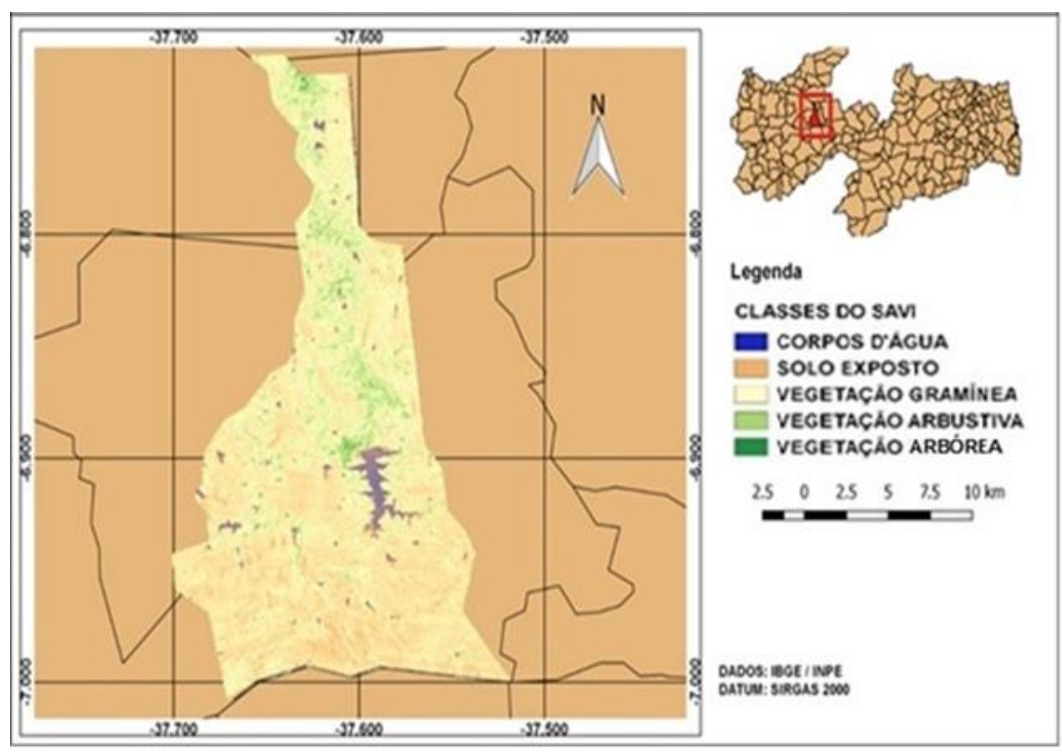

Fonte: Elaborado por Renato Rodrigues (2018).

Mesmo com a limitação visual no mapa, os produtos SAVI de 1999 e 2009 foram comparados observando-se poucas alterações na composição da vegetação. Os dados de 1999 apresentavam uma cobertura dos três componentes de 234,64 km², enquanto no ano de 2009 os números foram de 217,84 km², com uma redução de 16,8 km². Um dos fatos responsáveis pela redução da vegetação arbórea está associado ao crescente aumento do rebando bovino, pois a atividade agropecuária é uma das principais atividades econômicas da região.

Outra classe que apresentou crescimento com relação ao produto SAVI anterior foram os corpos d'água, houve crescimento de $50 \%$ e isto se deu principalmente em virtude do aumento considerável do volume hídrico do açude Engenheiro Arcoverde. De acordo com a AESA-PB (op. cit.), o reservatório passou de aproximadamente $9.164 .850 \mathrm{~m}^{3}, 30 \%$ da sua capacidade, para $35.776 .325 \mathrm{~m}^{3}$ o equivalente a $97 \%$ da sua capacidade. Com isso a área de espelhamento foi ampliada gerando maior reflectância desse elemento.

\section{Análise do uso e ocupação do solo no ano de 2018}

Conforme se observa na Figura 6 e na Tabela 4, a representação do SAVI do ano de 2018 apresentou similaridade na progressão do percentual dentre as classes de vegetação. A vegetação gramínea (ou herbácea) ficou distribuída em uma área de 
$56 \mathrm{~km}^{2}$, equivalente a $20 \%$ do território analisado e a vegetação arbustiva, com pouco mais de 25,3\%, ocupava uma área de $70,84 \mathrm{~km}^{2}$

O percentual de vegetação arbórea foi 4,7\% maior em relação a vegetação arbustiva, com uma área de 85,4 km², representando a maior porção do território. Comparando as vegetações arbóreas e gramíneas a diferença chega a 10\%. Diante da presença significativa da composição vegetal, a resolução espectral referente ao solo exposto representou $20 \%$ e as áreas de valores negativos representadas pelos corpos d'água corresponderam a 4,2\% ou 11,76 km².

Figura 6 - Mapa do SAVI do município de Condado/PB - 2018.

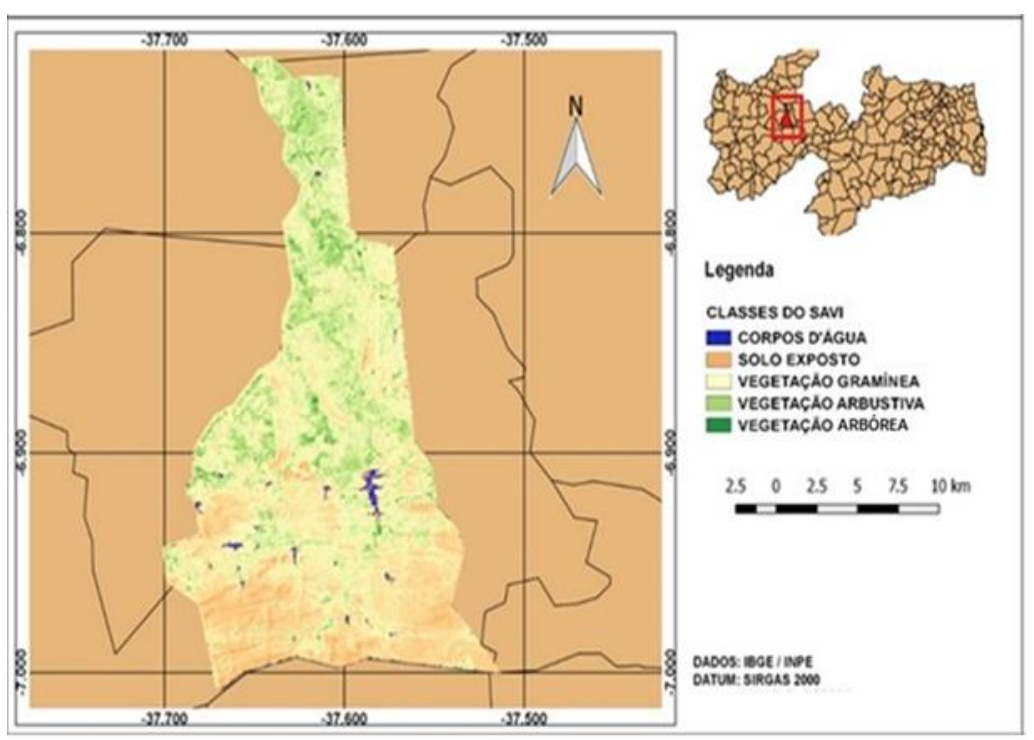

Fonte: Elaborado por Renato Rodrigues (2018).

Tabela 4 - Classes de cobertura, SAVI, Condado-PB - 2018.

\begin{tabular}{lcc}
\hline \multicolumn{1}{c}{ Classes } & Área $\left(\mathbf{k m}^{2}\right)$ & Percentual (\%) \\
\hline Vegetação arbórea & 30,5 & 85,4 \\
Vegetação arbustiva & 25,3 & 70,84 \\
Vegetação gramínea (ou herbácea) & 20 & 56 \\
Solo exposto & 20 & 56 \\
Corpos d'água & 4,2 & 11,76 \\
\hline \multicolumn{1}{c}{ Total } & $\mathbf{2 8 0}$ & $\mathbf{1 0 0}$ \\
\hline
\end{tabular}

Fonte: Elaborado por Renato Rodrigues (2018).

Tendo como parâmetro as imagens SAVI de 19/09/2009, observa-se que não ocorreram discrepantes alterações nas respostas espectrais referentes ao SAVI do ano de 2018. Analisando os fatores relacionados às condições naturais e antrópicas, observa-se que, na intersecção temporal entre as duas imagens, as precipitações foram registradas abaixo das médias para a região, caracterizando um longo período de estiagem que se iniciou no ano de 2013 e foi até o ano de 2017. Com tais condições pluviométricas, as condições naturais construíram paisagens que oscilaram, mas se reestabeleceram dentro da sua dinâmica. Nesse processo, a vegetação de Caatinga dispõe de três principais mecanismos de adaptação à escassez hídrica, quais sejam: (i) a resistência das espécies que permanecem enfolhadas no período seco; (ii) a tolerância das espécies caducifólias que perdem as folhas no início da estação seca; e (iii) o escape das plantas anuais que completam o ciclo fenológico durante a época chuvosa (Araújo Filho \& Carvalho, 1995). 
Fazendo uma síntese de todo o período estudado observa-se que a vegetação arbórea aumentou significativamente no ano de 1999, quando comparada com o ano de 1989. Os solos expostos em 1989 cobriam uma área de 149,72 km², o que representa mais da metade $(53,6 \%)$ da área territorial do município de Condado. Entretanto, houve uma redução bem significativa do solo exposto nos anos seguintes da série temporal, com participação relativa inferior aos $20 \%$ em extensão. Outra classe que merece destaque foi a da vegetação arbustiva, que permaneceu quase constante, com área significativa maior que os $70 \mathrm{~km}^{2}$ durante o período (Gráfico 1).

Gráfico 1 - Variação das Classes de Cobertura, SAVI, do município de Condado/PB - 1989 a 2018.

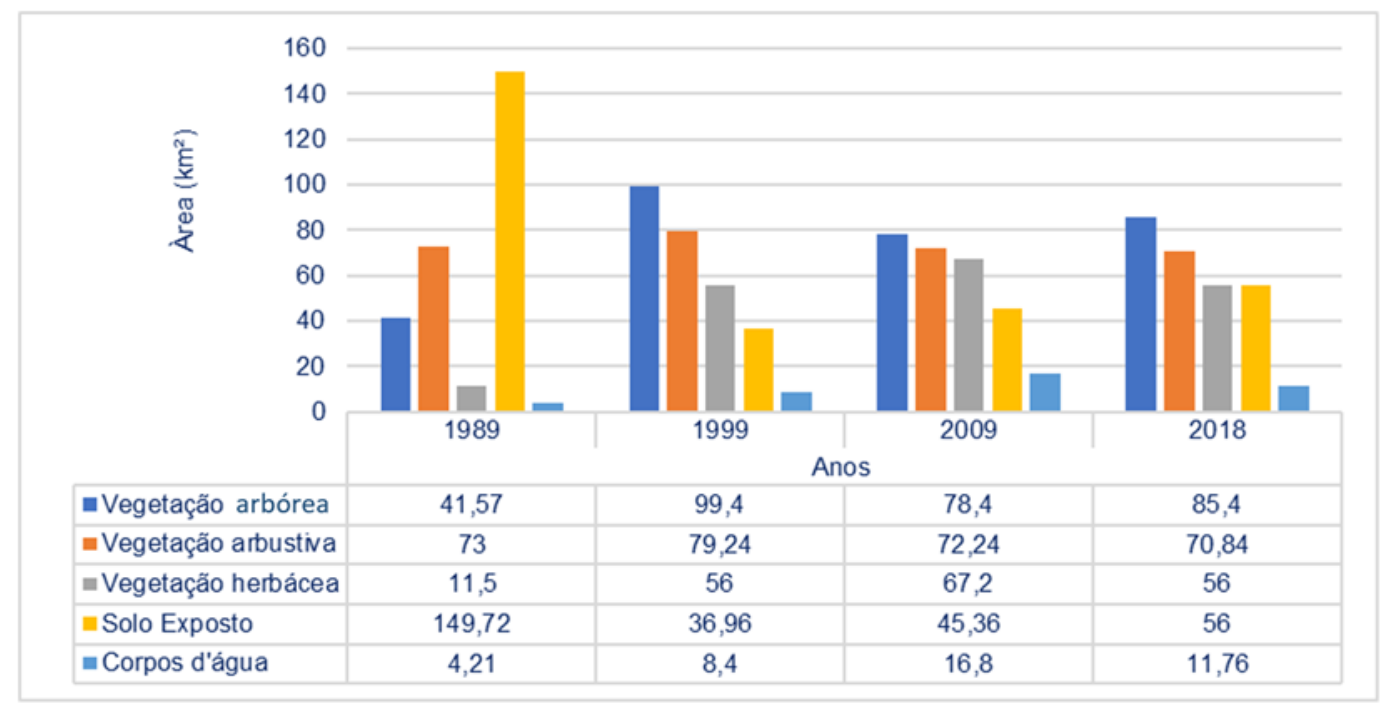

Fonte: Autores (2020).

Na região analisada, a supressão da cobertura vegetal ocorre com a finalidade de produzir pastagem, e a madeira de maior porte costuma ser utilizada na confecção de cercas divisórias entre as propriedades rurais e construção de currais. Estas atividades dão suporte a agropecuária tradicional local. O Gráfico 2, construído a partir de dados fornecidos pelo IBGE op.cit. (2018), mostra que o rebanho bovino no município de Condado apresentou um crescimento de $71 \%$, número que representa um acréscimo de 3.050 animais em cinco anos no período que compreende o período de 2004 a 2009.

Gráfico 2 - Efetivo do rebanho bovino do município de Condado - PB - 2004-2009.

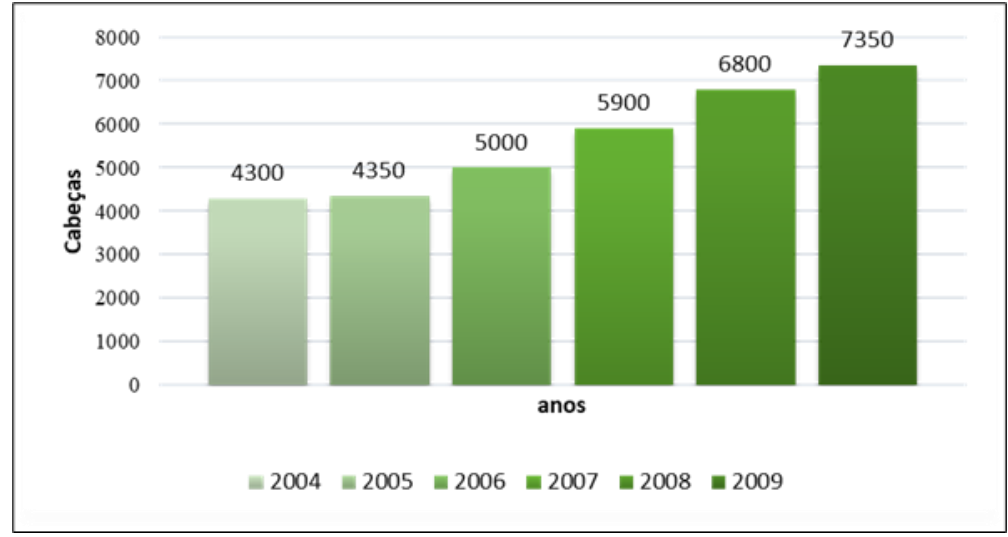

Fonte: IBGE (2018). 
Os Gráficos 3, 4 e 5 apresentam os quantitativos referentes às produções de madeira/lenha, do rebanho bovino e de grãos no intervalo temporal entre os anos de 2009 a 2017. Nesse período a produção de lenha permaneceu quase constante (entre 2.100 e $2.391 \mathrm{~m}^{3}$ ). Já o rebanho bovino apresentou oscilação no número de cabeças ao longo do período, tendo uma queda no efetivo nos anos de 2012 e 2013 e apresentando crescimento a partir de 2014 até voltar a superar o número de sete mil cabeças no ano de 2017.

No Gráfico 3, que representa a extração de madeira para a produção de lenha, observa-se que não ocorreu significativa variação na quantidade produzida entre os anos de 2009 a 2017, podendo ser este um dos fatores que evidencia a semelhança na manutenção dos resultados do produto gerado pelo SAVI. Assim como a supressão vegetal para a produção de lenha se manteve estável, o rebanho bovino, representado no Gráfico 4, também se apresentou praticamente com o mesmo número de animais, onde em 2009 o rebanho era composto por 7.350 cabeças e em 2017 o decréscimo foi de apenas 40 animais.

Gráfico 3 - Produção de lenha $\left(\mathrm{em} \mathrm{m}^{3}\right)$ no município de Condado-PB - 2009-2017

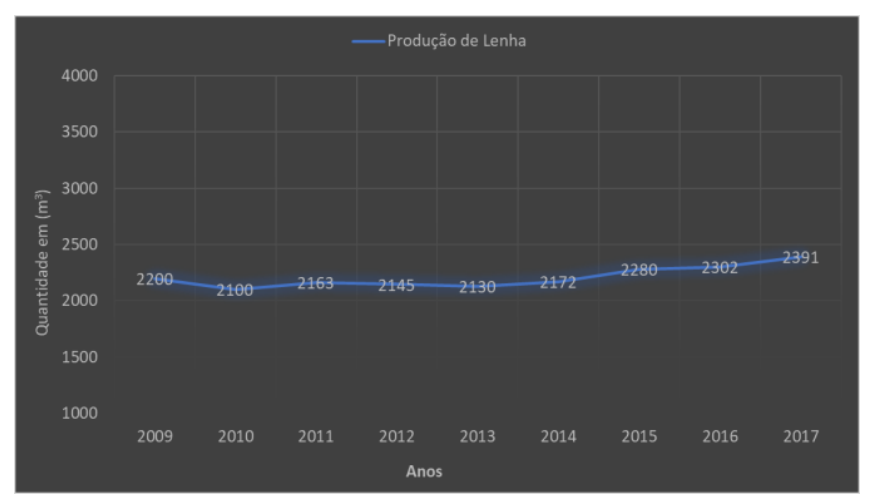

Fonte: IBGE (2018).
Gráfico 4 - Efetivo do Rebanho Bovino de Condado-PB $2009 / 2017$

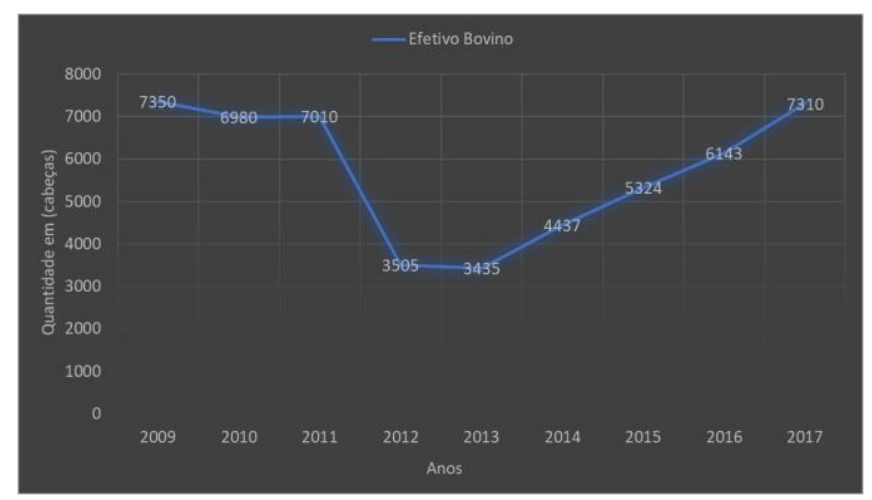

Fonte: IBGE (2018).

A extensão das áreas agrícolas de feijão e milho - principais culturas temporárias adotadas no município representada no Gráfico 5, seguem o mesmo padrão de continuidade das atividades anteriores, tendo maior discrepância na produção de milho com redução na área plantada de 110 hectares no comparativo das extremidades temporais do gráfico. É importante salientar que a fonte de dados (IBGE), não disponibiliza informações referentes ao ano de 2013 para produção de milho e feijão no município estudado.

Tratando-se de atividades que geram significativas alterações na paisagem, em decorrência da ausência de práticas de manejo e sustentabilidade no município, a análise das informações relativas as culturas de milho e feijão retrata as interferências antrópicas no comportamento das classes de uso e ocupação do solo na área estudada. 
Gráfico 5 - Área Plantada (ha) de milho e feijão no município de Condado-PB-2009-2017.

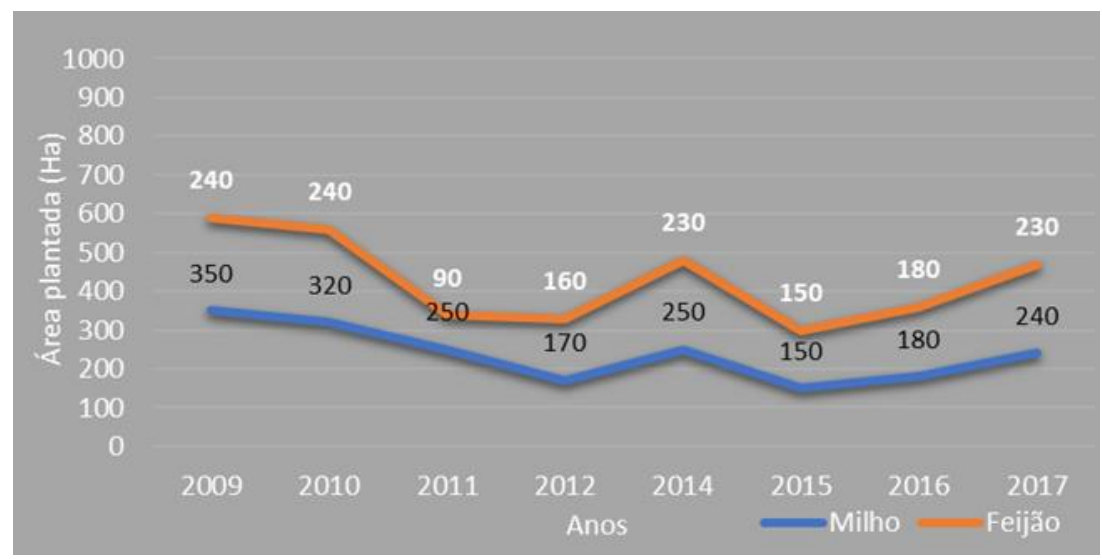

Fonte: IBGE (2018).

Ademais, a vegetação arbustiva e gramínea (ou herbácea) remanescente compreende principalmente a vegetação forrageira das espécies como o capim elefante (Pennisetum purpureum Schum) e braquiária cultivado nas áreas de várzea e no leito úmido do açude Engenheiro Arcoverde, utilizadas pelos pecuaristas para alimentar o rebanho bovino (Figura 7).

Figura 7 - Panorama do uso e ocupação do solo na área do perímetro irrigado do Açude Engenheiro Arcoverde, Condado PB.

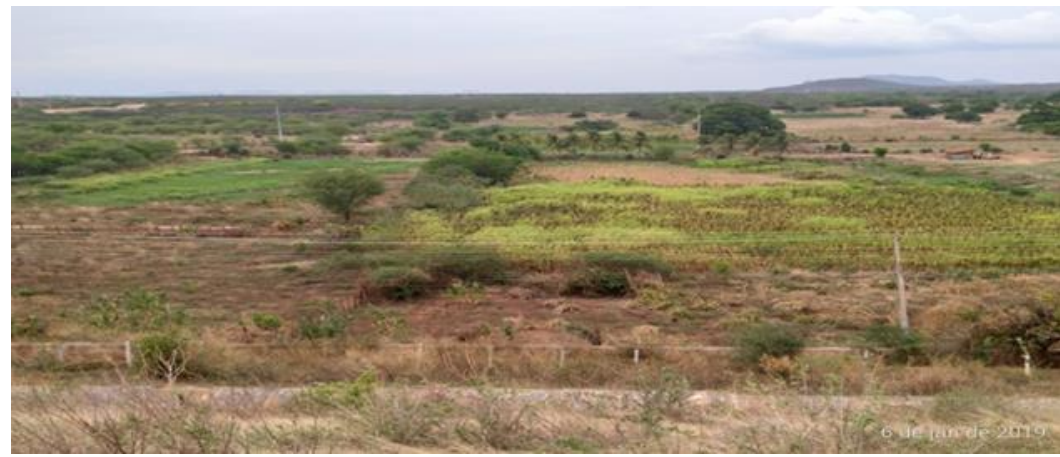

Fonte: Renato Rodrigues, (abril de 2016).

Embora a produção agrícola de grãos como feijão e milho representem atualmente uma área plantada de 150 ha no município de Condado, a região do Açude Engenheiro Arcoverde não apresenta em sua base produtiva esse tipo de cultura, isto, em virtude do direcionamento histórico implementado pelos órgãos que administravam a área e pelas associações que ao longo dos anos permaneceram com a mesma base, predominando nas áreas ao norte do reservatório a produção de frutas como Banana, Goiaba, Manga, Coco, entre outras.

Outras áreas com densidade de vegetação são formadas por espécies nativas perenifólias como o Juazeiro (Ziziphus joazeiro), a Oiticica (Licania rigida), e a Algaroba (Prosopis juliflora), que margeiam e integram a mata ciliar dos riachos da área estudada.

\section{Considerações Finais}

A análise da dinâmica espacial e temporal do uso e ocupação do solo no município de Condado-PB correspondeu aos postulados literários sobre as condições ambientais da Região Semiárida brasileira. A evolução espaço-temporal das configurações da paisagem, no período analisado, referendou os tipos tradicionais de exploração dos recursos ambientais peculiares à região estudada como condicionantes do panorama de uso e ocupação do solo do município. 
A investigação do tema possibilitou a compreensão dos processos antrópicos envolvidos na formação do ambiente estudado, bem como corroborou os pressupostos ambientais referentes ao ciclo fenológico e à resiliência da cobertura vegetal de Caatinga.

A metodologia utilizada, comum neste tipo de análise, conta com ampla bibliografia favorável a aplicação deste método analítico, porém, melhoramentos nos resultados podem ainda ser obtidos com a aplicação do algoritmo de máxima verossimilhança sobre a resposta espectral oriunda dos índices de vegetação, conforme se observou em algumas referências.

Dentro das expectativas pretendidas para um estudo local, a pesquisa satisfez o intuito original de mapear o uso e ocupação do solo no município de Condado, gerando conhecimento embasado no método científico para subsidiar pesquisas futuras sobre a temática abordada na região de abrangência do referido município.

\section{Referências}

Aragão, K. P., Bandeira, D. J., Lima, S. C., Oliveira, A. N., Lima, M. J., Nascimento, k. L., . . Moraes Neto, J. M. (2021). Gado Bravo-PB: uma análise da degradação ambiental. Research, Society and Development, 10(12), e383101220664. doi:http://dx.doi.org/10.33448/rsd-v10i12.20664

Araújo, E. D., Souza, J. O., \& Machado, C. C. (2021). Variação da vegetação e sua relação com o Índice topográfico de umidade - ITU no enclave subúmido das Serras Sertanejas-Paraíba, Nordeste, Brasil. RA'EGA, 50, 153-169. doi:http://dx.doi.org/10.5380/raega.v50i0.74614

Araújo Filho, J. A., Carvalho, F. C. (1995). Desenvolvimento sustentado da caatinga. Anais do Congresso Brasileiro De Ciência Do Solo. Viçosa, MG, 25.

Bandeira, T. V., \& Cruz, M. L. (2021). Estuda da Cobertura Vegetal do Município de Guaiúba/CE com Base na Utiização dos Índices de Vegetação SAVI e NDVI. Geosul, 410-433. doi:https://doi.org/10.5007/2177-5230.2021.e73138

Baptista, C. H. M. S., Moura, F. R., Silva, V. A., \& Andrade, J. L. (2018). Crédito rural e população rural na região Nordeste: Uma análise especial. Anais do XXI Encontro Nacional de Estudos Populacionais. Poço de caldas, MG, Brasil.

Bertrand, G. (2004). Paisagem e Geografia Física Global: esboço metodológico. RA'EGA, 8, 141-152. doi:http://dx.doi.org/10.5380/raega.v8i0

Bispo, P. d., Valeriano, M. d., \& Kuplich, T. M. (2010). Relação da Vegetação de Caatinga com a Condição Geomorfométrica Local . Revista Brasiliera de Engenharia Agrícola e Ambiental, 14(5), 523-530. http://www.agriambi.com.br

Dutra, D. J., Brianezi, D., \& Coelho, C. W. (1 de abril de 2020). Uso de Geotecnologias para Análise da Dinâmica da Vegetação da Sub-bacia do Ribeirão Serra Azul, MG. Anuário do Instituto de Geociências - UFRJ, 43, pp. 283-292. www.anuario.igeo.ufrj.br

Empresa Brasileira de Pesquisa Agropecuária. (10 de maio de 2018). Embrapa - Monitoramento por Satélite. Fonte: Banco de Dados Climáticos do Brasil: https://www.cnpm.embrapa.br/projetos/bdclima/balanco/resultados/pb/564/balanco.html

Figueiredo, J. M., Araújo, J. M., Lúcio, A. M., Bakke, I. A., \& Bakke, O. A. (2017). Regeneração Herbácea em Áreas Degradadas de Caatinga Enriquecidas com Árvore Nativas. Ciência Florestal, 27(4), 1143-1156. doi:https://doi.org/10.5902/1980509830292

Gobbi, L. D. (5 de fevereiro de 2019). Urbanização brasileira. São Paulo, São Paulo, Brasil. Fonte: http://educacao.globo.com/geografia/assunto/urbanizacao/ urbanizacao-brasileira.html

Huete, A. R. (1988). A Soil Adjusted Vegetation Index (SAVI). Remote Sensing of Environment, 295-309. doi:http://dx.doi.org/10.1016/00344257(88)90106-X

Instituto Brasileiro de Geografia e Estatística. (2 de março de 2018b). IBGE - Geociências. Fonte: Downloads - Shapefiles: https://www.ibge.gov.br/geoci encias/downloads-geociencias.html

Instituto Brasiliero de Geografia e Estatística. (10 de fevereiro de 2018a). IBGE. Fonte: IBGE - Cidades: https://cidades.ibge.gov.br/brasil /pb/condado/panorama

Lima Júnior C, Accioly LJO, Giongo V, Lima RLFA, Sampaio EVSB, Menezes RSC. (2014). Estimativa de biomassa lenhosa da caatinga com uso de equações alométricas e índice de vegetação. Scientia Forestalis, 42(102): 289-298.

Liu TDJ, Shanga J MBQB, Kovacs JM, Waltersb D, Jiao X, Genga X, Shia Y. (2019). Assessment of red-edge vegetation indices for crop leaf area index estimation. Remote Sensing of Environment. 222: 133-143. http://doi:10.3390/rs11091073

Machado, C. C., Galvíncio, J. D., \& Oliveira, T. H. (2011). Analise Espacial e Temporal do IVAS e do Albedo da Superfície no Município de São José do Sabugi-PB. Geografia, 36, 359-369. https://www.periodicos.rc.biblioteca.unesp.br/index.php/ageteo/ article/view/3883/5129

Neves, L. Z., \& Mucida, D. P. (2020). Comparação de Índices de Vegetação Entre Imagens CBERS, Landsat e Rapideye para Área do Cerrado Brasileiro. Revista Espinhoso, 9(1), 43-51. doi:https://doi.org/10.5281/zenodo.3937479

Ribeiro, G. d., Silva, J. N., \& Silva, J. B. (2016). Índe de Vegetação Ajustado ao Solo (IVAS): estado da arte e suas potencialidades. Revista Brasileira de Geografia Física, 9(6), 2054-2074. doi:https://doi.org/10.26848/rbgf.v9.6.p2054-2074 
Research, Society and Development, v. 11, n. 3, e8211326001, 2022

(CC BY 4.0) | ISSN 2525-3409 | DOI: http://dx.doi.org/10.33448/rsd-v11i3.26001

Rodrigues, R. d. (2019). Análise Espacial e Temporal do Uso e Cobertura do Solo no Entorno do Açude Engenheiro Arcoverde, Município de Condado-PB, no Período de 1989 a 2018. (Dissertação de mestrado). Universidade Federal de Campina Grande - UFCG, Campina Grande, PB, Brasil.

Serviço Geológico do Brasil. (1 de outubro de 2005). RIGeo. Fonte: Repositório Institucional de geociências - CPRM: https://rigeo.cprm.gov.br/xmlui/bitstream/handle/doc/16022/Rel_Condado.pdf?sequence=2

Souza, D. G., Sfair, J. C., Paula, A. S., Barros, M. F., Rito, K. F., \& Tabarelli, M. (2019). Multiple drivers of aboveground biomass in a human-modified landscape of the Caatinga dry forst. Forest Ecology and Management, 435, 57-65. doi:10.1016/j.foreco.2018.12.042 